Article

\title{
The Hyaluronan Pericellular Coat and Cold Atmospheric Plasma Treatment of Cells
}

\author{
Claudia Bergemann ${ }^{1, *}$, Anna-Christin Waldner ${ }^{1}$, Steffen Emmert ${ }^{2}$ and J. Barbara Nebe ${ }^{1}$ (i) \\ 1 Department of Cell Biology, University Medical Center Rostock, Schillingallee 69, \\ D-18057 Rostock, Germany; anna-christin.waldner@med.uni-rostock.de (A.-C.W.); \\ barbara.nebe@med.uni-rostock.de (J.B.N.) \\ 2 Clinic and Polyclinic for Dermatology and Venereology, University Medical Center Rostock, Strempelstrasse \\ 13, D-18057 Rostock, Germany; steffen.emmert@med.uni-rostock.de \\ * Correspondence: claudia.bergemann@med.uni-rostock.de
}

Received: 30 June 2020; Accepted: 20 July 2020; Published: 22 July 2020

check for updates

\begin{abstract}
In different tumors, high amounts of hyaluronan (HA) are correlated with tumor progression. Therefore, new tumor therapy strategies are targeting HA production and degradation. In plasma medicine research, antiproliferative and apoptosis-inducing effects on tumor cells were observed using cold atmospheric plasma (CAP) or plasma-activated media (PAM). Until now, the influence of PAM on the HA pericellular coat has not been the focus of research. PAM was generated by argon-plasma treatment of Dulbecco's modified Eagle's Medium via the kINPen ${ }^{\circledR} 09$ plasma jet. The HA expression on PAM-treated HaCaT cells was determined by flow cytometry and confocal laser scanning microscopy. Changes in the adhesion behavior of vital cells in PAM were observed by impedance measurement using the xCELLigence system. We found that PAM treatment impaired the HA pericellular coat of $\mathrm{HaCaT}$ cells. The time-dependent adhesion was impressively diminished. However, a disturbed HA coat alone was not the reason for the inhibition of cell adhesion because cells enzymatically treated with HAdase did not lose their adhesion capacity completely. Here, we showed for the first time that the plasma-activated medium (PAM) was able to influence the HA pericellular coat.
\end{abstract}

Keywords: hyaluronan; cold atmospheric plasma; plasma-activated media; kINPen; cell adhesion; keratinocytes

\section{Introduction}

Hyaluronan (HA) is a glycosaminoglycan and a main component of the extracellular matrix (ECM). HA can be found in connective tissues, cartilage, and in the vitreous body of vertebrates. This long-chain, linear polysaccharide is formed by hyaluronan synthases; it is then transported through the plasma membrane of the cell and into the ECM by ABC transporters [1-6]. HA plays an important role in cell attachment, proliferation, and migration and is a target molecule for improving initial cell adhesion to biomaterials used in implantology [7-9]. Fast cell attachment on the biomaterial surface regulates the cell-material contact and affects the "race for the surface" [10]. Positively charged biomaterial surfaces are shown to enhance the initial osteoblast cell adhesion by electrostatically attracting the cells through their pericellular HA coat [11-14]. After attachment of the cells to the biomaterial, the HA coat is degraded, and the cells build tighter connections by cell-ECM and cell-cell receptor interactions [15].

In cells' lives, HA has a divergent role depending on maturation and differentiation of the cell [16]. HA expression is high in cells with low differentiation or in tissues with high turnover, e.g., in wound healing. During mitosis, the expression of the HA pericellular coat contributes to the detachment of the 
cell from their surrounding as a precondition for cell division. After division, daughter cells attach to the surface again and degrade the hyaluronan by hyaluronidases (HAdase) [16]. However, tumor cells retain their HA coat and show high proliferation, but low differentiation rates, and HA is overexpressed in various tumor cells, e.g., in lung, colorectal, prostate, bladder, or breast carcinoma $[1,17,18]$.

Tumors are formed from cellular and acellular components and build up a so-called tumor microenvironment. In this complex system, besides malignant, immune, and stroma cells, the ECM components and secreted factors play an important role [19]. In tumors, stroma cells produce high amounts of HA, and accelerated HA synthesis is correlated with the aggressive behavior of tumor cells and tumor spreading [20,21]. Experimentally enhanced HA production stimulates tumor growth and metastasis in xenograft models, induces drug resistance, and promotes the invasiveness of tumor cells [22-24]. New tumor therapy strategies involve the inhibition of HA production and the promotion of the degradation of HA [21,25-28].

Another new approach in tumor therapy is the application of cold atmospheric plasma (CAP). Plasma medicine is a relatively new research field, which combines projects in physics, chemistry, biology, and medicine [29-31]. Physical plasmas are ionized gases consisting of ions, electrons, radicals, ultraviolet photons, and uncharged atoms or molecules. Plasma can be formed by supplying gases with high energy under atmospheric pressure. Cold plasma can be formed by supplying gases with high energy under atmospheric or low pressure. Low-pressure plasmas are used for decontamination/sterilization in the food industry and in medicine or for the specific modification of the surface properties of materials. For this purpose, samples are inserted into a chamber, which is evacuated and filled with certain gases; a discharge is then applied [12,32,33]. Here, we focused on cold atmospheric plasmas (CAP). For the generation of CAP, different plasma devices are used, for example, plasma jets or a dielectric barrier discharge [34]. Plasma medicine research focusses on the possibilities of medical applications of CAP to promote wound healing, disinfection, and tissue regeneration and in tumor therapy [34-36]. The influence of CAP on cells depends on the exposure time and the plasma strength, which is determined by parameters, such as distance from the nozzle, discharge voltage, gas composition, flow rate, and humidity [34,37-39]. Cold atmospheric plasmas generate short-lived molecules, such as reactive oxygen and nitrogen species (RONS). Reactive species with relatively long lifetimes, e.g., hydrogen peroxide, are generated by, in particular, the interaction of CAP with liquids [37,40,41]. Interestingly, plasma-treated cell culture media or buffers achieve similar effects on cells, as reported for direct plasma treatment of cells in liquids [42-47]. Plasma-activated media (PAM) can be made in advance and retain their biological efficiency during storage for up to 21 days [45,48-53]. In vitro experiments have revealed effects like reduced viability, detachment and apoptosis of cells, and DNA damage, as well as openings of the tight junction protein ZO-1 in cell-cell contacts $[44,45,48,54-58]$. Promising results have been shown regarding the selective killing of tumor cells alongside normal cells using CAP or PAM [57,59-65]. Clinically used buffer solutions like Ringer's lactate solution are also interesting targets for plasma activation. Plasma-treated Ringer's lactate solution has shown antitumor effects on different types of cancer both in vitro and in vivo [66-70]. To investigate the detachment and impaired adhesion of cells, other groups have examined the influence of CAP/PAM on molecules in adhesion complexes, e.g., integrins and cadherins or ZO-1 as a protein in tight junctions $[44,45,48,71-74]$.

We assumed that, in cells that express HA at their surface, e.g., tumor cells, the RONS generated during plasma therapy first reaches the cells HA coat before they can contact the molecules located in the cell membrane. This idea was further nourished by works showing that HA is degraded by free radicals [75-77]. This made it interesting to investigate whether, in addition to the antiproliferative and apoptosis-inducing effects described so far for plasma therapy, the influence of CAP/PAM on the HA pericellular coat could be another important target in tumor therapy and if it could influence tumor development and metastasis. To our knowledge, findings on these interesting research questions have not yet been published. 
Here, we described the first in vitro investigations on the influence of plasma-activated medium (PAM) on the hyaluronan pericellular coat of HaCaT keratinocytes. The PAM was generated by argon-plasma treatment of Dulbecco's modified Eagle's Medium (DMEM) via the kINPen ${ }^{\circledR} 09$ plasma jet $[44,78]$. The question arose whether PAM is able to reduce the HA pericellular coat in a manner similar to enzyme hyaluronidase.

\section{Materials and Methods}

\subsection{Argon Plasma Source}

The atmospheric pressure plasma jet kINPen ${ }^{\circledR} 09$ (Neoplas Tools GmbH, Greifswald, Germany) was used for all experiments. This plasma source was characterized in detail by Weltmann et al. [45,78]. The device consists of a quartz capillary (inner diameter of $1.6 \mathrm{~mm}$ ) with a needle electrode (diameter of $1 \mathrm{~mm}$ ) embedded in a hand-held unit connected to a DC power supply $(8 \mathrm{~W}$ at $220 \mathrm{~V}, 50-60 \mathrm{~Hz})$. A high-frequency voltage $(1.1 \mathrm{MHz}, 2-6 \mathrm{kV})$ is applied at the needle electrode. Settings at the DC power supply are $60 \mathrm{~V}$ and $54 \mathrm{~mA}$. Argon gas (purity 99.996\%) is used as a feed gas with a gas flow of $1.9 \mathrm{slm}$. A gas discharge is ignited at the tip of the high voltage needle, exciting the argon gas. In this way, low-temperature plasma is generated and blown out of the capillary. The so-called plasma jet outside the nozzle has a length of $12-14 \mathrm{~mm}$ and is about $1 \mathrm{~mm}$ wide. The temperature at the visible tip of the plasma jet does not exceed $50{ }^{\circ} \mathrm{C}$ [45]. Optical emission spectra were measured by Weltmann et al., and the data were shown in earlier works $[45,78]$.

\subsection{Cell Culture}

The nontumorigenic human keratinocyte cell line HaCaT was used throughout the experiments. This cell line represents spontaneously transformed keratinocytes from histologically normal adult skin [79]. HaCaT cells (CLS Cell Line Service GmbH, Eppelheim, Germany) were cultured in Dulbecco's modified Eagle's medium (DMEM; high glucose, GlutaMAX ${ }^{\mathrm{TM}}, 1 \mathrm{mM}$ pyruvate, 10569; Thermo Fisher Scientific, Gibco, Paisley, UK) supplemented with 10\% fetal calf serum (FCS Superior; Biochrom GmbH, Berlin, Germany) and 1\% Pen Strep solution (10,000 units/mL Penicillin, 10,000 $\mu \mathrm{g}$ Streptomycin/mL, Sigma-Aldrich. Dreieich, Germany) at $37^{\circ} \mathrm{C}$ and $5 \% \mathrm{CO}_{2}$. Near confluence, cells were detached with trypsin/ethylenediaminetetraacetic acid (0.25\% trypsin/0.38\% EDTA; Invitrogen, Gibco, Paisley, UK) for $13 \mathrm{~min}$. After stopping trypsinization by the addition of DMEM with $10 \%$ FCS, an aliquot of $100 \mu \mathrm{L}$ was put into $10 \mathrm{~mL}$ of CASY ${ }^{\circledR}$ ton buffer solution (OLS GmbH, Bremen, Germany), and the cell number was measured in the counter CASY ${ }^{\circledR}$ Model DT (Schärfe System, Reutlingen, Germany). After centrifugation (1200 rpm, $5 \mathrm{~min}$ ), the medium was replaced by serum-free DMEM with $1 \%$ Pen Strep solution, and the appropriate cell number was used, as described for the special experiments.

\subsection{Plasma Treatment of Cell Culture Media}

Serum-free DMEM with $1 \%$ Pen Strep was used throughout the experiments and is referred to as DMEM in the text. The medium underwent argon plasma treatment for $30 \mathrm{~s}$ (plasma-activated medium, PAM30) or $60 \mathrm{~s}$ (PAM60), as indicated for the specific experiment. For this purpose, $100 \mu \mathrm{L}$ of DMEM was supplied per well in a 96-well plate (Greiner Bio-One, Kremsmünster, Austria). The kINPen ${ }^{\circledR} 09$ was mounted vertically, and the quartz capillary was positioned at the top edge of each well in the 96-well plate. The distance between the tip of the quartz capillary and the 96-well plate did not exceed $1 \mathrm{~mm}$. In this way, the argon plasma had immediate contact with the media $[45,80]$. Argon gas treatment using the $\mathrm{kINPen}{ }^{\circledR} 09$ without igniting the plasma for $60 \mathrm{~s}$ was used as a control (argon-activated medium, AAM). Untreated DMEM was included as a further control. After plasma treatment, the different samples and controls were pooled in separate tubes (1.5 mL; Eppendorf, Hamburg, Germany). For subsequent cell experiments, these media were stored at $37^{\circ} \mathrm{C}$ and $5 \%$ $\mathrm{CO}_{2}$ for $24 \mathrm{~h}$ to ensure that the cell effects observed were neither caused by the changed oxygen 
concentrations nor by the persistence of hydrogen peroxide; these were shown to be balanced over $24 \mathrm{~h}$ after plasma treatment [45].

As a further control, suspended $\mathrm{HaCaT}$ cells were preincubated with hyaluronidase (HAdase, 600 units/mL, type IV-S, H-4272, Sigma, Steinheim, Germany) under slightly shaking for $30 \mathrm{~min}$ $\left(37^{\circ} \mathrm{C}\right)$ in serum-free DMEM with $1 \%$ Pen Strep (because HAdase is inactive in serum-containing media) and then seeded into DMEM with HAdase (600 units/mL, DMEM + HAdase) and cultivated for the appropriate times. Furthermore, HaCaT cells were incubated in DMEM supplemented with hydrogen peroxide $\left(\mathrm{H}_{2} \mathrm{O}_{2}\right)$ to test the effect of a relatively long-lived reactive species, which usually arises from the interaction of CAP with a liquid medium. We used a concentration of $150 \mathrm{mg} / \mathrm{L} \mathrm{H}_{2} \mathrm{O}_{2}$ (from commercial stock solution, 30\%, Fisher Scientific) in DMEM corresponding to the concentrations measured in an earlier study of our group [80].

\subsection{Hyaluronan Expression}

To analyze the expression of hyaluronan (HA) in HaCaT cells depending on the media used, $1.25 \times 10^{6}$ cells $/ \mathrm{mL}$ were seeded into PAM30, PAM60, and control media in a cell culture $\mu$-Dish $35 \mathrm{~mm}$ (ibidi $\mathrm{GmbH}$ ) and cultivated for 3 or $6 \mathrm{~h}$ at $37^{\circ} \mathrm{C}$ and $5 \% \mathrm{CO}_{2}$. After cultivation for $3 \mathrm{~h}$, cells from the supernatant were collected by centrifugation ( $1200 \mathrm{rpm}, 5 \mathrm{~min}$ ) and pooled from 5 dishes for each PAM sample and 10 dishes each for control experiments with DMEM, AAM, and HAdase. HA expression was quantified by flow cytometry. For this purpose, cells were fixed with $4 \%$ paraformaldehyde (Merck, Steinheim, Germany), stained with $2 \mathrm{mg}$ biotinylated HA binding protein (Calbiochem, San Diego, CA, USA) for $120 \mathrm{~min}$, followed by incubation with $0.5 \mathrm{mg}$ streptavidin-FITC (Becton Dickinson, San Diego, CA, USA) for additional $30 \mathrm{~min}$ at room temperature in the dark. An extra DMEM sample was incubated with $0.5 \mathrm{mg}$ streptavidin-FITC only and served as a blank control. Measurements of the fluorescence and light scatter characteristics of 10,000 cells were performed by flow cytometry (ext. 488, em. 519; FACSCalibur, BD Bioscience, Heidelberg, Germany). Data were analyzed by FlowJo ${ }^{\mathrm{TM}}$ 7.6.5 for Windows (FlowJo LLC, Tree Star Inc., Ashland, OR, USA) for three independent experiments.

After $6 \mathrm{~h}$ of culture, cells were fixed and stained for HA, as described for flow cytometry. In addition, the nucleus of the cells was stained with Hoechst $33342(10 \mathrm{mg} / \mathrm{mL}, 1: 1000$ in PBS, Invitrogen), and cell images were taken with a confocal laser scanning microscope (LSM 780, Carl Zeiss, Jena, Germany; objective $63 \times$ oil).

\subsection{Cell Adhesion of Vital Cells}

Cell adhesion was investigated using the xCELLigence RTCA (Real-time Cell Analysis) S16 Instrument (ACEA Biosciences, San Diego, CA, USA). The xCELLigence system allows real-time and label-free monitoring of living cell adhesion, vitality, and proliferation. The system consists of a 16-well electronic microtiter plate (E-plate), the RTCA Station, which is placed into an incubator at $37^{\circ} \mathrm{C}$ and $5 \% \mathrm{CO}_{2}$, the RTCA impedance analyzer, and a computer with RTCA software to control the system action/mode. For the experiments, we used the E-plate VIEW 16 (ACEA Biosciences).

First, PAM30, PAM60, and control media were equilibrated to room temperature. To measure the baseline impedance, $100 \mu \mathrm{L}$ of PAM or control media was added to the appropriate well in the xCELLigence E-plate, and the background measurement was performed. Then, HaCaT cells (96,000 cells/well in $100 \mu \mathrm{L}$ of the appropriate medium) were seeded into the E-plate, obtaining a total volume of $200 \mu \mathrm{L}$ in each well. The change in impedance caused by cell adhesion, spreading, and proliferation was measured continuously for $1.5 \mathrm{~h}$ at $37^{\circ} \mathrm{C}$ and $5 \% \mathrm{CO}_{2}$. Data were analyzed by the RTCA Data Analysis Software 1.0 and displayed as the cell index (CI) value in real-time. CI values were normalized by subtracting the corresponding background value at the corresponding time. Attachment of $\mathrm{HaCaT}$ cells was presented as the normalized CI for three independently performed experiments with two technical replicates each. 


\subsection{Cell Viability}

To monitor the viability of the cells in PAM30, PAM60, and control samples, the CellTiter $96{ }^{\circledR}$ AQueous Non-Radioactive Cell Proliferation Assay (Promega, Madison, WI, USA) was used. Cells were seeded into a 96-well plate $(96,000$ cells/well) with $200 \mu \mathrm{L}$ of the appropriate medium (three wells each). After an incubation time of $48 \mathrm{~h}\left(37{ }^{\circ} \mathrm{C}\right.$ and $\left.5 \% \mathrm{CO}_{2}\right), 40 \mu \mathrm{L}$ of the 3-(4,5-dimethylthiazol-2-yl)-5-(3-carboxymethoxyphenyl)-2-(4-sulfophenyl)-2H-tetrazolium solution (MTS, inner salt; Promega) was added to each well and incubated for $60 \mathrm{~min}\left(37^{\circ} \mathrm{C}\right.$ and $\left.5 \% \mathrm{CO}_{2}\right)$ with manual shaking every $10 \mathrm{~min}$. After this, $70 \mu \mathrm{L}$ of each well was transferred into a new 96 -well plate, and the absorption was determined at $492 \mathrm{~nm}$ (reference $620 \mathrm{~nm}$ ) using a microplate reader (Anthos 2010, Anthos Labtec Instruments, Wals-Siezenheim, Austria). The appropriate medium without cells served as a blank. The viability of cells was calculated corresponding to cells in the untreated control medium $(100 \%)$. The determination of cell viability was performed in three independent experiments with three technical replicates each.

\subsection{Statistics}

Statistical analysis of datasets was performed using the software SPSS 15.0 for Windows (SPSS Inc., Chicago, IL, USA). Data are expressed as mean \pm standard error of the mean (s.e.m.) and analyzed using the unpaired $t$-test. Statistical analyses for the xCELLigence measurements were performed using GraphPad PRISM Version 7.02 for Windows (GraphPad Software Inc., La Jolla, CA, USA) with the Mann-Whitney test for three time-points $(0.5,1.0$, and $1.5 \mathrm{~h})$. Differences were considered statistically significant at $p<0.05\left({ }^{*} p<0.05,{ }^{* *} p<0.01,{ }^{* * *} p<0.001\right)$.

\section{Results}

The aim of this study was to evaluate the influence of PAM on the HA pericellular coat and, in this context, the adhesion of vital HaCaT keratinocytes. We used the kINPen ${ }^{\circledR} 09$ plasma jet to generate PAM from Dulbecco's modified Eagle's medium (DMEM) by argon-plasma treatment for different times and argon-gas treatment without igniting the plasma. Untreated DMEM and HAdase-supplemented DMEM served as controls. As a further control, DMEM was supplemented with hydrogen peroxide to test the effect of a relatively long-lived reactive species, which usually arises from the interaction of CAP with a liquid medium. We referred to the different samples as follows: untreated DMEM as DMEM, DMEM treated by argon plasma for $30 \mathrm{~s}$ as PAM30, DMEM treated by argon plasma for $60 \mathrm{~s}$ as PAM60, DMEM treated by argon gas without igniting the plasma for $60 \mathrm{~s}$ as AAM, DMEM supplemented with HAdase as HAdase, and DMEM supplemented with hydrogen peroxide as $\mathrm{H} 2 \mathrm{O} 2$. Our first preliminary results were obtained on non-tumorigenic human HaCaT cells and are presented here.

\subsection{Impairment of the HA Pericellular Coat}

To determine the effect of PAM treatment on the pericellular HA coat, HaCaT cells were collected from the supernatant after $3 \mathrm{~h}$ of culture, stained for HA, and measured by flow cytometry. As shown in Figure 1, the fluorescence signal for HA was significantly lower for HaCaT cells cultivated in PAM than in control media, but not as low as for cells treated enzymatically with HAdase, where the fluorescence intensity was only around values of 55. The effect was more pronounced for PAM60 than for PAM30, where we measured values of about 75 and 113, respectively.

Additionally, the appearance of the cells was compared for HaCaT cells after cultivation in PAM or control media for $3 \mathrm{~h}$ using the light-scattering properties measured by flow cytometry. The forward scatter (FSC) indicates the approximate cell size, and the sideward scatter (SSC) yields information about the granularity of the cell, the size, and structure of its nucleus and the number of vesicles in it. In our measurements, we did not find any changes in the size and granularity of the cells in suspension after cultivation in PAM for $3 \mathrm{~h}$. Figure 2 shows exemplarily the dot plots from cells in DMEM and PAM60. 


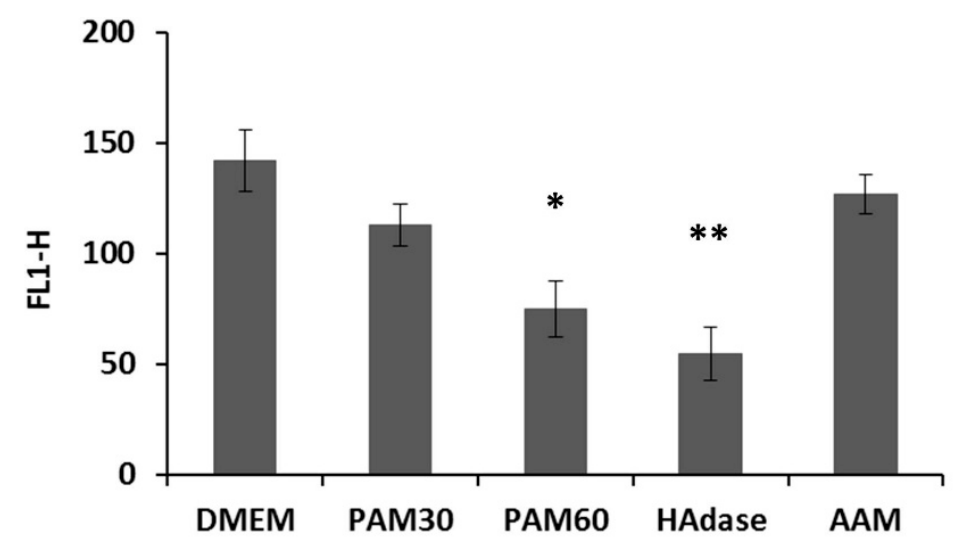

Figure 1. Flow cytometry determination of the hyaluronan (HA) expression in non-adherent HaCaT cells after cultivation in plasma-activated media (PAM) or control media for $3 \mathrm{~h}$. Note that the fluorescence intensity for HA was reduced depending on the plasma treatment time used for generation of the PAM (mean \pm s.e.m., $\mathrm{n}=3$, unpaired $t$-test, ${ }^{*} p<0.05,{ }^{* *} p<0.01$ ). Abbr.: FL1-H: fluorescence intensity, DMEM: Dulbecco's modified Eagle's medium, PAM30: 30 s plasma-treated DMEM, PAM60: 60 s plasma-treated DMEM, AAM: 60 s argon gas-treated DMEM, HAdase: DMEM with hyaluronidase.
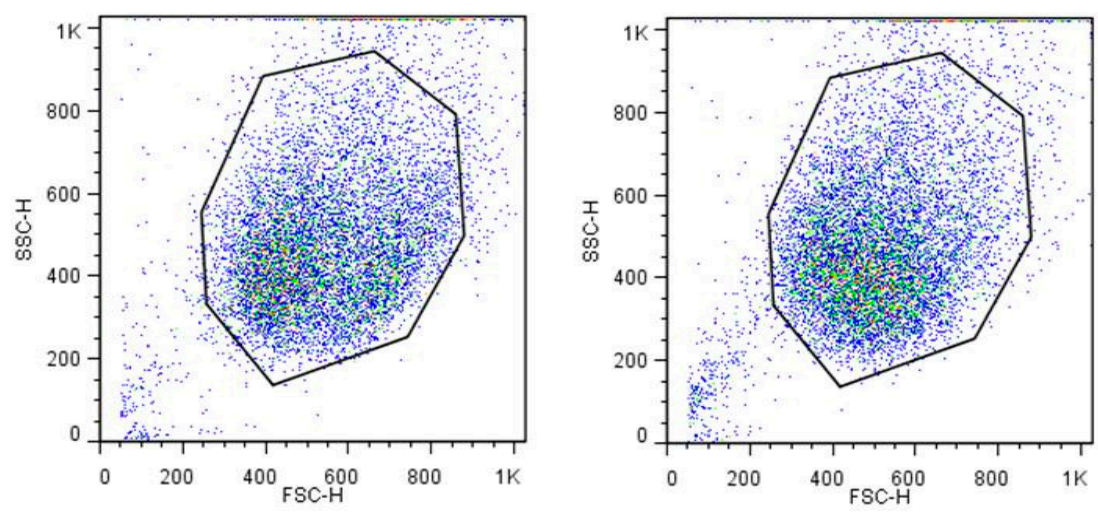

Figure 2. Flow cytometry determination of size and granularity of $\mathrm{HaCaT}$ cells after cultivation in DMEM (left) or PAM60 (right) for $3 \mathrm{~h}$. No decisive differences can be seen between the dot plots of forward (FSC) and sideward scatter (SSC). Abbr.: DMEM: Dulbecco's modified Eagle's medium, PAM60: 60 s plasma-treated DMEM.

For the visualization of the changes in the HA pericellular coat, HaCaT cells were stained for HA by biotinylated HA binding protein and streptavidin-FITC and detected by confocal laser scanning microscopy. Representative images of HaCaT cells after $6 \mathrm{~h}$ in PAM and control media are shown in Figure 3. The HA pericellular coat was impaired in cells cultivated in PAM-especially in PAM60—but did not show any changes for cells in AAM. The influence of PAM on the HA coat depended on the plasma treatment time used for the generation of the PAM. HaCaT cells treated with HAdase completely lost their HA coat after $6 \mathrm{~h}$ of incubation.

After culture for 3 or $6 \mathrm{~h}$ in PAM, HaCaT cells showed an impaired HA pericellular coat. Because HA plays an important role in cell attachment, it was interesting to investigate if the impairment of the HA coat by culture in PAM has a significant effect on the adhesion and the viability of HaCaT cells. 

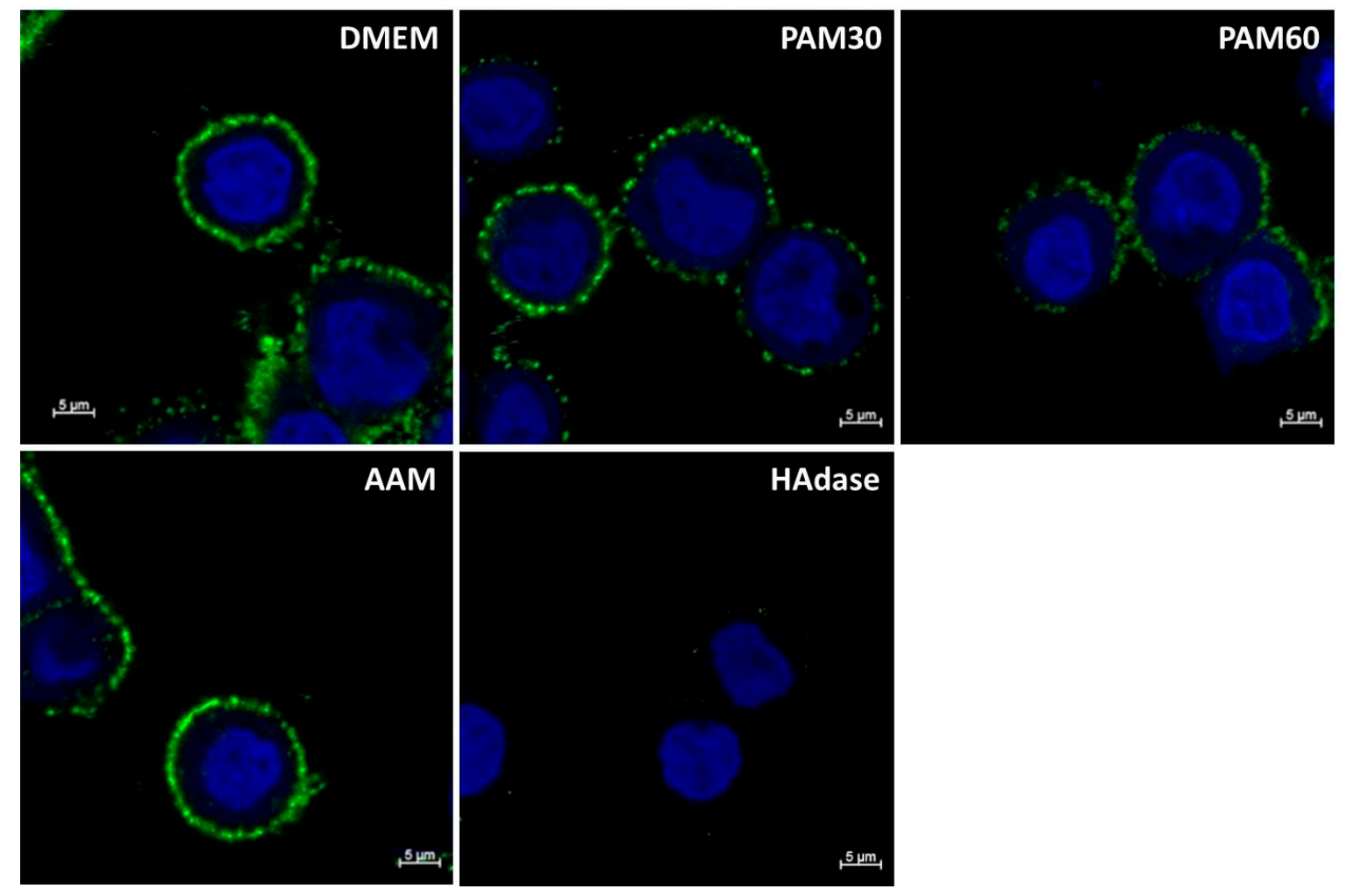

Figure 3. Immune fluorescence images of the HA pericellular coat of HaCaT cells (HA-green, nuclei -blue) after cultivation in PAM or control media for $6 \mathrm{~h}$. Note that the HA coat was reduced in PAM30 and PAM60. (LSM780, Carl Zeiss, objective $63 \times$ oil, zoom 2.5, bar $=5 \mu \mathrm{m}$ ). Abbr.: DMEM: Dulbecco's modified Eagle's medium, PAM30: 30 s plasma-treated DMEM, PAM60: 60 s plasma-treated DMEM, AAM: $60 \mathrm{~s}$ argon gas-treated DMEM, HAdase: DMEM with hyaluronidase.

\subsection{Influence of PAM on the Cell Adhesion and Viability of HaCaT}

To determine the effect of PAM on the adhesion of HaCaT cells, we used the xCELLigence system. This system allows the real-time monitoring of living cell adhesion, spreading, and vitality. As shown in Figure 4, the adhesion of $\mathrm{HaCaT}$ cells in PAM over $1.5 \mathrm{~h}$ was significantly reduced compared with cells cultivated in the DMEM control, whereas no altered adhesion was observed for cells cultivated in AAM. This effect was the same for both PAM30 and PAM60, i.e., independent of the plasma treatment time used to produce the PAM. In PAM30 and PAM60, the normalized cell index after $1.5 \mathrm{~h}$ reached values of about 0.197 and 0.189 , respectively, whereas, in DMEM, the value was about 0.397 . Interestingly, HAdase-treated cells showed only slight impairment of the cell adhesion within $1.5 \mathrm{~h}$, and the normalized cell index was 0.302 . This effect was not significant.

The cell viability was determined after $48 \mathrm{~h}$ culture in PAM by MTS assay. Figure 5 shows that the viability was significantly reduced compared with DMEM. This effect was stronger in PAM60 than in PAM30. The viability of HAdase-treated cells was also reduced after $48 \mathrm{~h}$ and was in a range similar to the cells cultivated in PAM30. But this effect was not significant.

In summary, PAM treatment impaired the HA pericellular coat of $\mathrm{HaCaT}$ cells. Furthermore, the influence of PAM on the viability and the time-dependent adhesion was higher than after HAdase treatment. HAdase reduced the HA pericellular coat of the HaCaT cells almost completely, but this deficiency did not lead to a comparable loss of cell adhesion, suggesting additional effects of PAM on cell adhesion mechanisms. 


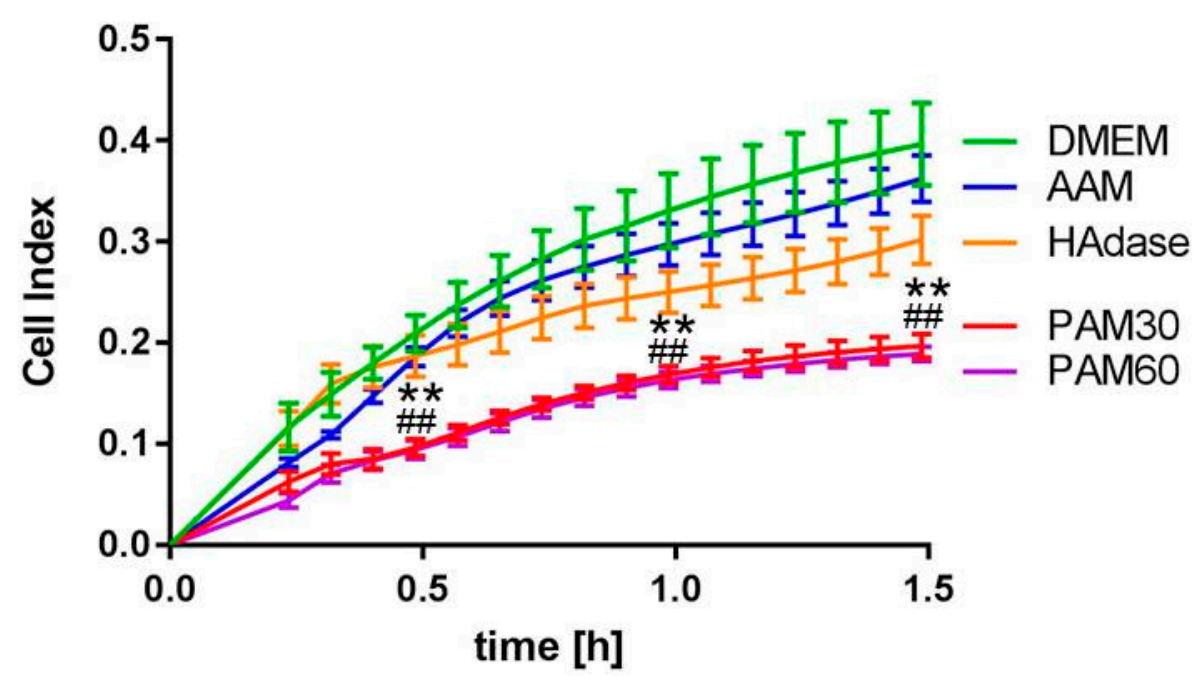

Figure 4. Online monitoring of HaCaT cell adhesion in PAM30, PAM60, and control media up to $1.5 \mathrm{~h}$. Note that PAM impaired the cell attachment process significantly and to a greater extent than the HAdase-cleavage did. (xCELLigence Real-time Cell Analysis, normalized cell index; mean \pm s.e.m., $\mathrm{n}=3$, Mann-Whitney test, ${ }^{* *} p<0.01$ PAM30 vs. DMEM, \#\# $p<0.01$ PAM60 vs. DMEM). Abbr.: DMEM: Dulbecco's modified Eagle's medium, PAM30: 30 s plasma-treated DMEM, PAM60: 60 s plasma-treated DMEM, AAM: $60 \mathrm{~s}$ argon gas-treated DMEM, HAdase: DMEM with hyaluronidase.

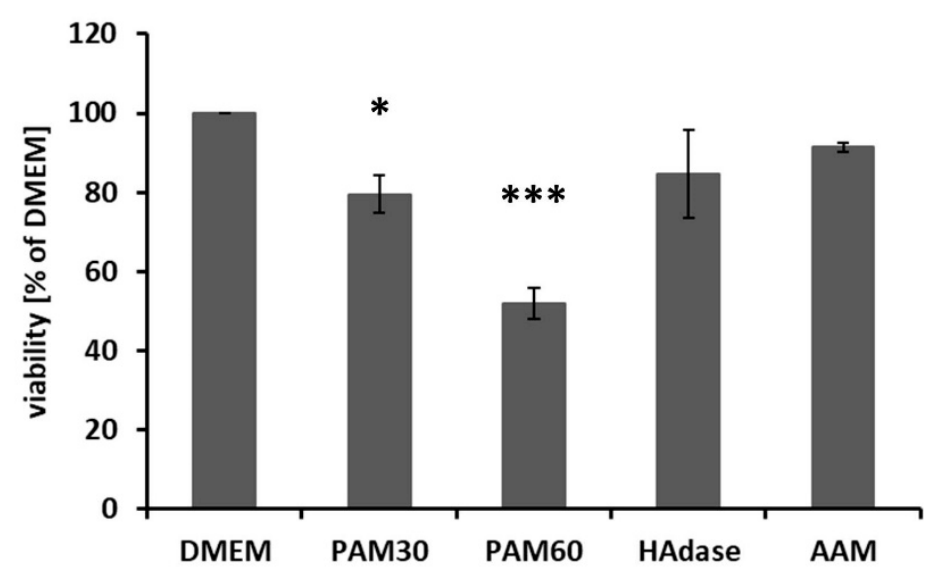

Figure 5. Cell viability of HaCaT cells after cultivation in the different PAM or control media for $48 \mathrm{~h}$. The cell viability was decreased in PAM depending on the treatment time used for generation of PAM (mean \pm s.e.m., $\mathrm{n}=3$, unpaired $t$-test, ${ }^{*} p<0.05,{ }^{* * *} p<0.001$ ). Abbr.: DMEM: Dulbecco's modified Eagle's medium, PAM30: 30 s plasma-treated DMEM, PAM60: 60 s plasma-treated DMEM, AAM: $60 \mathrm{~s}$ argon gas-treated DMEM, HAdase: DMEM with hyaluronidase.

\subsection{Influence of the Plasma Species $\mathrm{H}_{2} \mathrm{O}_{2}$ on Cell Adhesion}

To find out more about the mechanism underlying the action of PAM on the HA pericellular coat and the impairment of the cell adhesion, we incubated HaCaT cells in DMEM supplemented with $150 \mathrm{mg} / \mathrm{L}$ hydrogen peroxide $\left(\mathrm{H}_{2} \mathrm{O}_{2}\right)$ for $3 \mathrm{~h}$, stained cells from the supernatant for HA, and measured the HA fluorescence intensity by flow cytometry. In addition, we monitored the living cell adhesion of $\mathrm{HaCaTs}$ in DMEM containing $\mathrm{H}_{2} \mathrm{O}_{2}(\mathrm{H} 2 \mathrm{O} 2)$ over $1.5 \mathrm{~h}$ using the xCELLigence system. As shown in Figure 6, both the HA pericellular coat and the adhesion of the cells were impaired by $\mathrm{H} 2 \mathrm{O} 2$, but not as strong as by PAM. The fluorescence signal of labeled HA was significantly lower for cells in $\mathrm{H} 2 \mathrm{O} 2$ vs. DMEM, but not as low as for PAM60 (mean fluorescence channels 139, 107, 113, and 75 for DMEM, $\mathrm{H} 2 \mathrm{O} 2$, PAM30, and PAM60, respectively, see also Figure 1). The cell adhesion was significantly reduced in $\mathrm{H} 2 \mathrm{O} 2$ vs. DMEM (normalized cell index 0.231 vs. 0.397 , respectively). We could deduce from this 
that the adhesion of $\mathrm{HaCaT}$ cells was impaired by $\mathrm{H} 2 \mathrm{O} 2$ but not as strongly as by PAM30 and PAM60 (normalized cell index nearly 1.9 for both, see also Figure 4).

A

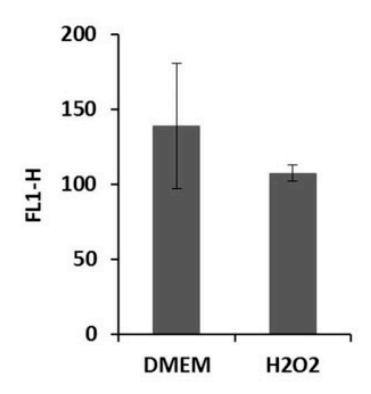

B

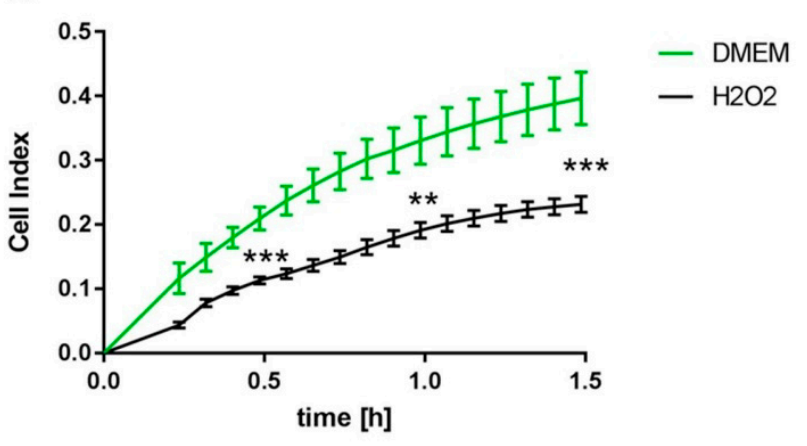

Figure 6. Influence of hydrogen peroxide on HaCaT cells in DMEM. (A) Flow cytometry determination of the HA expression in non-adherent HaCaT cells after cultivation in H2O2 or DMEM for $3 \mathrm{~h}$ (mean \pm s.e.m., $\mathrm{n}=2$ ). (B) Online monitoring of HaCaT cell adhesion in $\mathrm{H} 2 \mathrm{O} 2$ and DMEM up to $1.5 \mathrm{~h}$. Note that both the HA pericellular coat and the adhesion of the cells were impaired by $\mathrm{H} 2 \mathrm{O} 2$ (xCELLigence Real-time Cell Analysis, normalized cell index; mean \pm s.e.m., $\mathrm{n}=3$, Mann-Whitney test, ${ }^{* *} p<0.01,{ }^{* * *} p<0.001$ DMEM vs. H2O2). Abbr.: FL1-H: fluorescence intensity, DMEM: Dulbecco's modified Eagle's medium, H2O2: DMEM with $\mathrm{H}_{2} \mathrm{O}_{2}$.

With these first additional investigations, we could show that the effect of PAM on HaCaT cells was not solely mediated by the relatively longer-lived reactive species $\mathrm{H}_{2} \mathrm{O}_{2}$ contained in PAM. The impairment of the cells in $\mathrm{H} 2 \mathrm{O} 2$ was not as strong as in PAM. Future experiments will shed light on further species involved in the mechanism of action of the complex mixture of PAM on the HA coat.

\section{Discussion}

HA is a component of the ECM and is expressed in the tumor microenvironment formed by malignant cells, immune cells, and stroma cells [19]. In some cancers, high amounts of HA are correlated with tumor progression $[20,21]$. In tumor therapy, various strategies are pursued. One is to influence the tumor microenvironment by inhibiting the HA synthesis using drugs like 4-methylumbelliferone or promoting degradation by HAdases in combination with chemotherapy [21,25-28]. Another approach is the use of physical plasma to selectively affect tumor cells alongside normal cells [57-65]. Both strategies could be combined by influencing the HA pericellular coat of cells through physical plasma. Since this has not been investigated so far [19], we determined the influence of PAM on the HA pericellular coat of $\mathrm{HaCaT}$ cells in vitro.

Pinhal et al. determined the amount of HA produced by HaCaT keratinocytes using a fluorimetric measurement [81]. In our study, using immune fluorescence staining and confocal laser scanning microscopy, we could show for the first time that $\mathrm{HaCaT}$ cells express the HA as a pericellular coat. We also found that the expression of HA could be reduced by incubation with PAM. Interestingly, this time-dependent effect was not comparable to HAdase treatment, where $\mathrm{HaCaT}$ cells completely lost their HA coat after $6 \mathrm{~h}$ of incubation. However, PAM had a significant effect on the adhesion of $\mathrm{HaCaT}$ cells during the whole observation time of $1.5 \mathrm{~h}$ and was much more pronounced than that of HAdase, which was only detectable after $30 \mathrm{~min}$.

Interestingly, HAdase treatment seems to affect the initial cell adhesion of HaCaT cells less than that of osteoblasts. In an earlier work of our group, we found a significantly reduced initial adhesion of HAdase-treated MG-63 osteoblast cells on titanium compared to untreated cells during the first $15 \mathrm{~min}$ [11], whereas the adhesion of HaCaT cells was only significantly affected by HAdase after an incubation time of $30 \mathrm{~min}$. It would seem it is difficult to compare the behaviors of different cell types. 
Osteoblasts are bone-forming cells, which synthesize great numbers of extracellular matrix molecules, e.g., collagen I and glycosaminoglycans.

$\mathrm{HaCaT}$ cells are human adult keratinocytes that are spontaneously immortalized and non-tumorigenic [79]. We used this cell line for the in vitro experiments described here as a model for human keratinocytes that also express relatively high amounts of HA. The HA content in different tissues varies greatly. Amounts in the skin are comparatively high and higher in fetal and young skin than in older skin [17]. Interestingly, in melanoma or other epidermal cancers, the HA content does not correlate with the tumor progression [82], and reduced expression of HA is found to be a marker for poor survival in oral squamous cell carcinoma [81,83].

To find out more about the mechanism underlying the action of PAM on the HA pericellular coat, we tested a relatively long-lived reactive species, which usually arises from the interaction of CAP with a liquid medium, hydrogen peroxide $\left(\mathrm{H}_{2} \mathrm{O}_{2}\right)$. We incubated $\mathrm{HaCaT}$ cells in DMEM supplemented with $150 \mathrm{mg} / \mathrm{L} \mathrm{H}_{2} \mathrm{O}_{2}$. We chose this concentration because, in previous work, we found an $\mathrm{H}_{2} \mathrm{O}_{2}$ content of $120 \mathrm{mg} / \mathrm{L}$ for DMEM without pyruvate directly after CAP exposure and could show that the $\mathrm{H}_{2} \mathrm{O}_{2}$ was depleted immediately by pyruvate in DMEM with $1 \mathrm{mM}$ pyruvate [80]. In consideration of other anti-oxidative components contained in DMEM, such as $\mathrm{Fe}^{3+}$, which leads to the decomposition of $\mathrm{H}_{2} \mathrm{O}_{2}$ by the Fenton reaction, we used the concentration of $150 \mathrm{mg} / \mathrm{L}$. We could show that the effect of PAM on HaCaT cells was not solely mediated by $\mathrm{H}_{2} \mathrm{O}_{2}$ contained in PAM. Although $\mathrm{H}_{2} \mathrm{O}_{2}$ is an important molecule in PAM, it is not the only longer-living reactive species. As other groups have shown, after approx. $40 \mathrm{~h}$, nothing of the original concentrations can be detected [37]. From our own previous work, we know that the effect of PAM on cells lasts over 21 days [13]. One possible explanation is the formation of long-lived organic hydroperoxides [84]. It has already been shown that individually added RONS in cell culture medium or buffer does not have the same effect as PAM, but that the various reactive species that are formed as a complex mixture by CAP treatment in liquids complement each other in their effect $[37,85-87]$. Therefore, investigations to discover the mechanisms of action of CAP on cells in fluids are difficult and require special techniques. Simulation techniques appear to be also promising [88].

In terms of viability, we showed that PAM had a stronger inhibiting effect on HaCaT cells than the HAdase treatment. HAdase treatment led to an impairment of the outer layer of the cell and the degradation of the HA pericellular coat, but the effect of PAM extended into the interior of the cell. This is not surprising, and many effects of PAM or CAP on cells in vitro, e.g., apoptosis or DNA damage, are already known and have been described in several publications $[13,34-36,42-47,58]$.

Focused on the influence of CAP or PAM on the adhesion and migration of cells, other groups have examined the expression of adhesion molecules, e.g., integrins and cadherins or CD44, on cells after $\mathrm{CAP} / \mathrm{PAM}$ treatment in vitro. Haertel et al. found elevated integrin expression in HaCaT cells after direct or indirect Dielectric Barrier Discharge plasma treatment, whereby cadherin expression was not influenced [71,72]. In tumors, high cell migration rates are a precondition for tumor cell invasion into the surrounding tissue. Therefore, it is interesting that reduced cell migration was shown in vitro for fibroblast cells treated by CAP using a helium plasma jet [74]. Volotskova et al. explained this effect also by increased integrin activation and an elevated focal adhesion size.

We assumed that, in cells that express HA at their surface, the RONS generated during plasma treatment first reach the cells' HA coat before they contact the adhesion molecules, e.g., integrin receptors, located in the cell membrane. Since HA is degraded by free radicals [75-77], one can also imagine that the HA coat of the cells is degraded when treated with PAM. We were able to prove this for $\mathrm{HaCaT}$ cells with our investigations. Furthermore, it would be interesting to find out whether other glucosaminoglycan-coupled processes in cells are also regulated by PAM treatment. As such, it is possible that the decreasing HA expression is balanced in the cells by a higher HA receptor expression. We found these considerations confirmed in investigations by $\mathrm{Xu}$ et al. They investigated the influence of a helium jet plasma on the differentiation and adhesion of myeloma cells and found an elevated mRNA expression for the HA receptor molecule CD44 [89]. This fell in with our results such that 
the cells might try to compensate for a reduced HA expression by an increased expression of the corresponding receptor.

Here, we showed for the first time that, in addition to the known effects of CAP/PAM on cells, PAM also influences the HA pericellular coat, which is also a target in tumor therapy. To our knowledge, it has not yet been attempted to influence this target by plasma. We presented here the preliminary results of our research, which prompts new questions. In future studies, we will investigate the further temporal course of the HA expression after plasma treatment, and we will also include tumor cells. Because HA is synthesized by HA synthases in the cell membrane, we are also interested in determining the influence of plasma on the HA synthases.

Author Contributions: Conceptualization, C.B. and J.B.N.; methodology, C.B. and A.-C.W.; validation, C.B. and A.-C.W.; formal analysis, C.B. and A.-C.W.; investigation, C.B. and A.-C.W.; writing-original draft preparation, C.B. and A.-C.W.; writing-review and editing, J.B.N. and S.E.; project administration, J.B.N. and S.E.; funding acquisition, S.E. and J.B.N. All authors have read and agreed to the published version of the manuscript.

Funding: The final experiments were financially supported by ONCOTHER-H. This joint research project was funded by the European Social Fund (ESF), reference: ESF/14-BM-A55-0002/18, and the Ministry of Education, Science and Culture of Mecklenburg-Vorpommern, Germany.

Acknowledgments: The authors would like to thank Petra Seidel, Finja Hildebrandt, and Thomas Freitag (Dept. of Cell Biology, University Medical Center Rostock) for qualified technical assistance. We thank Lars Boeckmann (UMR, Clinic and Polyclinic for Dermatology and Venereology) for the HaCaT cells.

Conflicts of Interest: The authors declare no conflict of interest. The funders had no role in the design of the study; in the collection, analyses, or interpretation of data; in the writing of the manuscript, or in the decision to publish the results.

\section{References}

1. Toole, B.P. Hyaluronan: From extracellular glue to pericellular cue. Nat. Rev. Cancer 2004, 4, 528-539. [CrossRef]

2. Weigel, P.H.; Hascall, V.C.; Tammi, M. Hyaluronan synthases. J. Biol. Chem. 1997, 272, 13997-14000. [CrossRef] [PubMed]

3. Tammi, M.I.; Day, A.J.; Turley, E.A. Hyaluronan and homeostasis: A balancing act. J. Biol. Chem. 2002, 277, 4581-4584. [CrossRef] [PubMed]

4. Hubbard, C.; McNamara, J.T.; Azumaya, C.; Patel, M.S.; Zimmer, J. The hyaluronan synthase catalyzes the synthesis and membrane translocation of hyaluronan. J. Mol. Biol. 2012, 418, 21-31. [CrossRef] [PubMed]

5. Schulz, T.; Schumacher, U.; Prehm, P. Hyaluronan export by the ABC transporter MRP5 and its modulation by intracellular cGMP. J. Biol. Chem. 2007, 282, 20999-21004. [CrossRef] [PubMed]

6. Dicker, K.T.; Gurski, L.A.; Pradhan-Bhatt, S.; Witt, R.L.; Farach-Carson, M.C.; Jia, X. Hyaluronan: A simple polysaccharide with diverse biological functions. Acta Biomater. 2014, 10, 1558-1570. [CrossRef]

7. Cohen, M.; Joester, D.; Geiger, B.; Addadi, L. Spatial and temporal sequence of events in cell adhesion: From molecular recognition to focal adhesion assembly. Chembiochem 2004, 5, 1393-1399. [CrossRef]

8. Zaidel-Bar, R.; Cohen, M.; Addadi, L.; Geiger, B. Hierarchical assembly of cell-matrix adhesion complexes. Biochem. Soc. Trans. 2004, 32, 416-420. [CrossRef]

9. Nebe, B.; Lüthen, F. Integrin-and hyaluronan-mediated cell adhesion on titanium. Met. Biomater. Interact. 2008, 179-182.

10. Gristina, A.G.; Naylor, P.; Myrvik, Q. Infections from biomaterials and implants: A race for the surface. Med. Prog. Through Technol. 1988, 14, 205-224.

11. Finke, B.; Luethen, F.; Schroeder, K.; Mueller, P.D.; Bergemann, C.; Frant, M.; Ohl, A.; Nebe, B.J. The effect of positively charged plasma polymerization on initial osteoblastic focal adhesion on titanium surfaces. Biomaterials 2007, 28, 4521-4534. [CrossRef] [PubMed]

12. Nebe, J.B.; Rebl, H.; Schlosser, M.; Staehlke, S.; Gruening, M.; Weltmann, K.D.; Walschus, U.; Finke, B. Plasma Polymerized Allylamine-The Unique Cell-Attractive Nanolayer for Dental Implant Materials. Polymers 2019, 11, 1004. [CrossRef] [PubMed] 
13. Bergemann, C.; Cornelsen, M.; Quade, A.; Laube, T.; Schnabelrauch, M.; Rebl, H.; Weißmann, V.; Seitz, H.; Nebe, B. Continuous cellularization of calcium phosphate hybrid scaffolds induced by plasma polymer activation. Mater. Sci. Eng. C 2016, 59, 514-523. [CrossRef]

14. Rebl, H.; Finke, B.; Schmidt, J.; Mohamad, H.S.; Ihrke, R.; Helm, C.A.; Nebe, J.B. Accelerated cell-surface interlocking on plasma polymer-modified porous ceramics. Mater. Sci. Eng. C Mater. Biol. Appl. 2016, 69, 1116-1124. [CrossRef]

15. Cohen, M.; Kam, Z.; Addadi, L.; Geiger, B. Dynamic study of the transition from hyaluronan- to integrin-mediated adhesion in chondrocytes. EMBO J. 2006, 25, 302-311. [CrossRef] [PubMed]

16. Stern, R. CHAPTER 1-Association between Cancer and "Acid Mucopolysaccharides": An Old Concept Comes of Age, Finally. In Hyaluronan in Cancer Biology; Stern, R., Ed.; Academic Press: San Diego, CA, USA, 2009; pp. 3-16. [CrossRef]

17. Cowman, M.K.; Lee, H.G.; Schwertfeger, K.L.; McCarthy, J.B.; Turley, E.A. The Content and Size of Hyaluronan in Biological Fluids and Tissues. Front. Immunol. 2015, 6, 261. [CrossRef] [PubMed]

18. Tammi, R.H.; Kultti, A.; Kosma, V.M.; Pirinen, R.; Auvinen, P.; Tammi, M.I. Hyaluronan in human tumors: Pathobiological and prognostic messages from cell-associated and stromal hyaluronan. Semin. Cancer Biol. 2008, 18, 288-295. [CrossRef]

19. Privat-Maldonado, A.; Bengtson, C.; Razzokov, J.; Smits, E.; Bogaerts, A. Modifying the Tumour Microenvironment: Challenges and Future Perspectives for Anticancer Plasma Treatments. Cancers 2019, 11, 1920. [CrossRef]

20. Tammi, R.H.; Kultti, A.H.; Kosma, V.-M.; Pirinen, R.; Auvinen, P.; Tammi, M.I. CHAPTER 14-Hyaluronan in Human Tumors: Importance of Stromal and Cancer Cell-Associated Hyaluronan. In Hyaluronan in Cancer Biology; Stern, R., Ed.; Academic Press: San Diego, CA, USA, 2009; pp. 257-284. [CrossRef]

21. Briggs, A.; Rosenberg, L.; Buie, J.D.; Rizvi, H.; Bertagnolli, M.M.; Cho, N.L. Antitumor effects of hyaluronan inhibition in desmoid tumors. Carcinogenesis 2015, 36, 272-279. [CrossRef]

22. Kosaki, R.; Watanabe, K.; Yamaguchi, Y. Overproduction of hyaluronan by expression of the hyaluronan synthase Has2 enhances anchorage-independent growth and tumorigenicity. Cancer Res. 1999, 59, 1141-1145.

23. Itano, N.; Sawai, T.; Miyaishi, O.; Kimata, K. Relationship between hyaluronan production and metastatic potential of mouse mammary carcinoma cells. Cancer Res. 1999, 59, 2499-2504. [PubMed]

24. Koyama, H.; Hibi, T.; Isogai, Z.; Yoneda, M.; Fujimori, M.; Amano, J.; Kawakubo, M.; Kannagi, R.; Kimata, K.; Taniguchi, S.; et al. Hyperproduction of hyaluronan in neu-induced mammary tumor accelerates angiogenesis through stromal cell recruitment: Possible involvement of versican/PG-M. Am. J. Pathol. 2007, 170, 1086-1099. [CrossRef] [PubMed]

25. Stern, R. CHAPTER 12-Hyaluronidases in Cancer Biology. In Hyaluronan in Cancer Biology; Stern, R., Ed.; Academic Press: San Diego, CA, USA, 2008; pp. 207-220. [CrossRef]

26. Baumgartner, G.; Hamilton, G. CHAPTER 19-Clinical Use of Hyaluronidase in Combination Cancer Chemotherapy: A Historic Perspective. In Hyaluronan in Cancer Biology; Stern, R., Ed.; Academic Press: San Diego, CA, USA, 2009; pp. 363-378. [CrossRef]

27. Kakizaki, I.; Kojima, K.; Takagaki, K.; Endo, M.; Kannagi, R.; Ito, M.; Maruo, Y.; Sato, H.; Yasuda, T.; Mita, S.; et al. A novel mechanism for the inhibition of hyaluronan biosynthesis by 4-methylumbelliferone. J. Biol. Chem. 2004, 279, 33281-33289. [CrossRef] [PubMed]

28. Yoshihara, S.; Kon, A.; Kudo, D.; Nakazawa, H.; Kakizaki, I.; Sasaki, M.; Endo, M.; Takagaki, K. A hyaluronan synthase suppressor, 4-methylumbelliferone, inhibits liver metastasis of melanoma cells. FEBS Lett. 2005, 579, 2722-2726. [CrossRef] [PubMed]

29. Weltmann, K.D.; Von Woedtke, T. Plasma medicine-Current state of research and medical application. Plasma Phys. Contr. Fusion 2017, 59. [CrossRef]

30. Kaushik, N.K.; Ghimire, B.; Li, Y.; Adhikari, M.; Veerana, M.; Kaushik, N.; Jha, N.; Adhikari, B.; Lee, S.J.; Masur, K.; et al. Biological and medical applications of plasma-activated media, water and solutions. Biol. Chem. 2018, 400, 39-62. [CrossRef]

31. Kong, M.G.; Kroesen, G.; Morfill, G.; Nosenko, T.; Shimizu, T.; van Dijk, J.; Zimmermann, J.L. Plasma medicine: An introductory review. New J. Phys. 2009, 11. [CrossRef]

32. Moisan, M.; Barbeau, J.; Moreau, S.; Pelletier, J.; Tabrizian, M.; Yahia, L.H. Low-temperature sterilization using gas plasmas: A review of the experiments and an analysis of the inactivation mechanisms. Int. J. Pharm. 2001, 226, 1-21. [CrossRef] 
33. Lippens, P. Low-pressure cold plasma processing technology. Plasma Technol. Text. 2007, 64-78. [CrossRef]

34. von Woedtke, T.; Reuter, S.; Masur, K.; Weltmann, K.D. Plasmas for medicine. Phys. Rep. 2013, 530, $291-320$. [CrossRef]

35. Daeschlein, G.; von Woedtke, T.; Kindel, E.; Brandenburg, R.; Weltmann, K.D.; Junger, M. Antibacterial Activity of an Atmospheric Pressure Plasma Jet Against Relevant Wound Pathogens in vitro on a Simulated Wound Environment. Plasma Process Polym. 2010, 7, 224-230. [CrossRef]

36. Nastuta, A.V.; Topala, I.; Grigoras, C.; Pohoata, V.; Popa, G. Stimulation of wound healing by helium atmospheric pressure plasma treatment. J. Phys. D Appl. Phys. 2011, 44. [CrossRef]

37. Winter, J.; Tresp, H.; Hammer, M.U.; Iseni, S.; Kupsch, S.; Schmidt-Bleker, A.; Wende, K.; Dunnbier, M.; Masur, K.; Weltmannan, K.D.; et al. Tracking plasma generated H2O2 from gas into liquid phase and revealing its dominant impact on human skin cells. J. Phys. D Appl. Phys. 2014, 47. [CrossRef]

38. Winter, J.; Wende, K.; Masur, K.; Iseni, S.; Dunnbier, M.; Hammer, M.U.; Tresp, H.; Weltmann, K.D.; Reuter, S. Feed gas humidity: A vital parameter affecting a cold atmospheric-pressure plasma jet and plasma-treated human skin cells. J. Phys. D Appl. Phys. 2013, 46. [CrossRef]

39. Schmidt, A.; Bekeschus, S.; Jablonowski, H.; Barton, A.; Weltmann, K.D.; Wende, K. Role of Ambient Gas Composition on Cold Physical Plasma-Elicited Cell Signaling in Keratinocytes. Biophys. J. 2017, 112, 2397-2407. [CrossRef] [PubMed]

40. Graves, D.B. Oxy-nitroso shielding burst model of cold atmospheric plasma therapeutics. Clin. Plasma Med. 2014, 2, 38-49. [CrossRef]

41. Sato, T.; Yokoyama, M.; Johkura, K. A key inactivation factor of HeLa cell viability by a plasma flow. J. Phys. D Appl. Phys. 2011, 44. [CrossRef]

42. Kalghatgi, S.; Kelly, C.M.; Cerchar, E.; Torabi, B.; Alekseev, O.; Fridman, A.; Friedman, G.; Azizkhan-Clifford, J. Effects of Non-Thermal Plasma on Mammalian Cells. PLoS ONE 2011, 6. [CrossRef]

43. Haertel, B.; Wende, K.; von Woedtke, T.; Weltmann, K.D.; Lindequist, U. Non-thermal atmospheric-pressure plasma can influence cell adhesion molecules on HaCaT-keratinocytes. Exp. Derm. 2011, 20, 282-284. [CrossRef]

44. Hoentsch, M.; von Woedtke, T.; Weltmann, K.D.; Nebe, J.B. Time-dependent effects of low-temperature atmospheric-pressure argon plasma on epithelial cell attachment, viability and tight junction formation in vitro. J. Phys. D Appl. Phys. 2012, 45. [CrossRef]

45. Hoentsch, M.; Bussiahn, R.; Rebl, H.; Bergemann, C.; Eggert, M.; Frank, M.; von Woedtke, T.; Nebe, B. Persistent Effectivity of Gas Plasma-Treated, Long Time-Stored Liquid on Epithelial Cell Adhesion Capacity and Membrane Morphology. PLoS ONE 2014, 9. [CrossRef] [PubMed]

46. Dobrynin, D.; Fridman, G.; Friedman, G.; Fridman, A. Physical and biological mechanisms of direct plasma interaction with living tissue. New J. Phys. 2009, 11. [CrossRef]

47. Jablonowski, H.; von Woedtke, T. Research on plasma medicine-relevant plasma-liquid interaction: What happened in the past five years? Clin. Plasma Med. 2015, 3, 42-52. [CrossRef]

48. Bergemann, C.; Gerling, T.; Hoppe, C.; Karmazyna, M.; Hoentsch, M.; Eggert, M.; Nebe, B. Physicochemical Analysis of Argon Plasma-Treated Cell Culture Medium. In Plasma Science and Technology_Progress in Physical States and Chemical Reactions; Tetsu Mieno, IntechOpen: Rijeka, Croatia, 2016.

49. Utsumi, F.; Kajiyama, H.; Nakamura, K.; Tanaka, H.; Mizuno, M.; Ishikawa, K.; Kondo, H.; Kano, H.; Hori, M.; Kikkawa, F. Effect of indirect nonequilibrium atmospheric pressure plasma on anti-proliferative activity against chronic chemo-resistant ovarian cancer cells in vitro and in vivo. PLoS ONE 2013, 8. [CrossRef]

50. Tanaka, H.; Mizuno, M.; Ishikawa, K.; Nakamura, K.; Kajiyama, H.; Kano, H.; Kikkawa, F.; Hori, M. Plasma-activated medium selectively kills glioblastoma brain tumor cells by down-regulating a survival signaling molecule, AKT kinase. Plasma Med. 2011, 1, 265-277. [CrossRef]

51. Adachi, T.; Tanaka, H.; Nonomura, S.; Hara, H.; Kondo, S.I.; Hori, M. Plasma-activated medium induces A549 cell injury via a spiral apoptotic cascade involving the mitochondrial-nuclear network. Free Radic. Biol. Med. 2015, 79, 28-44. [CrossRef] [PubMed]

52. Joslin, J.M.; McCall, J.R.; Bzdek, J.P.; Johnson, D.C.; Hybertson, B.M. Aqueous plasma pharmacy: Preparation methods, chemistry, and therapeutic applications. Plasma Med. 2016, 6, 135-177. [CrossRef]

53. Wende, K.; von Woedtke, T.; Weltmann, K.-D.; Bekeschus, S. Chemistry and biochemistry of cold physical plasma derived reactive species in liquids. Biol. Chem. 2018, 400, 19-38. [CrossRef] 
54. Hirst, A.M.; Simms, M.S.; Mann, V.M.; Maitland, N.J.; O'Connell, D.; Frame, F.M. Low-temperature plasma treatment induces DNA damage leading to necrotic cell death in primary prostate epithelial cells. Br. J. Cancer 2015, 112, 1536-1545. [CrossRef]

55. Welz, C.; Emmert, S.; Canis, M.; Becker, S.; Baumeister, P.; Shimizu, T.; Morfill, G.E.; Harreus, U.; Zimmermann, J.L. Cold Atmospheric Plasma: A Promising Complementary Therapy for Squamous Head and Neck Cancer. PLoS ONE 2015, 10, e0141827. [CrossRef]

56. Kalghatgi, S.; Kelly, C.; Cerchar, E.; Azizkhan-Clifford, J. Selectivity of Non-Thermal Atmospheric-Pressure Microsecond-Pulsed Dielectric Barrier Discharge Plasma Induced Apoptosis in Tumor Cells over Healthy Cells. Plasma Med. 2011, 1, 249-263. [CrossRef]

57. Keidar, M.; Shashurin, A.; Volotskova, O.; Ann Stepp, M.; Srinivasan, P.; Sandler, A.; Trink, B. Cold atmospheric plasma in cancer therapy. Phys. Plasmas 2013, 20. [CrossRef]

58. Semmler, M.L.; Bekeschus, S.; Schafer, M.; Bernhardt, T.; Fischer, T.; Witzke, K.; Seebauer, C.; Rebl, H.; Grambow, E.; Vollmar, B.; et al. Molecular Mechanisms of the Efficacy of Cold Atmospheric Pressure Plasma (CAP) in Cancer Treatment. Cancers 2020, 12, 269. [CrossRef] [PubMed]

59. Stoffels, E.; Kieft, I.E.; Sladek, R.E.J.; van den Bedem, L.J.M.; van der Laan, E.P.; Steinbuch, M. Plasma needle for in vivo medical treatment: Recent developments and perspectives. Plasma Sources Sci. Technol. 2006, 15, S169-S180. [CrossRef]

60. Schlegel, J.; Köritzer, J.; Boxhammer, V. Plasma in cancer treatment. Clin. Plasma Med. 2013, 1, 2-7. [CrossRef]

61. Graves, D.B. Low temperature plasma biomedicine: A tutorial review. Phys. Plasmas 2014, $21,080901$. [CrossRef]

62. Tanaka, H.; Mizuno, M.; Ishikawa, K.; Kondo, H.; Takeda, K.; Hashizume, H.; Nakamura, K.; Utsumi, F.; Kajiyama, H.; Kano, H.; et al. Plasma with high electron density and plasma-activated medium for cancer treatment. Clin. Plasma Med. 2015, 3, 72-76. [CrossRef]

63. Hirst, A.M.; Frame, F.M.; Arya, M.; Maitland, N.J.; O'Connell, D. Low temperature plasmas as emerging cancer therapeutics: The state of play and thoughts for the future. Tumor Biol. 2016, 37, 7021-7031. [CrossRef]

64. Yan, D.; Talbot, A.; Nourmohammadi, N.; Sherman, J.H.; Cheng, X.; Keidar, M. Toward understanding the selective anticancer capacity of cold atmospheric plasma-A model based on aquaporins (Review). Biointerphases 2015, 10, 040801. [CrossRef]

65. Ratovitski, E.A.; Cheng, X.; Yan, D.; Sherman, J.H.; Canady, J.; Trink, B.; Keidar, M. Anti-cancer therapies of 21st century: Novel approach to treat human cancers using cold atmospheric plasma. Plasma Process Polym. 2014, 11, 1128-1137. [CrossRef]

66. Tanaka, H.; Nakamura, K.; Mizuno, M.; Ishikawa, K.; Takeda, K.; Kajiyama, H.; Utsumi, F.; Kikkawa, F.; Hori, M. Non-thermal atmospheric pressure plasma activates lactate in Ringer's solution for anti-tumor effects. Sci. Rep. 2016, 6. [CrossRef] [PubMed]

67. Tanaka, H.; Mizuno, M.; Katsumata, Y.; Ishikawa, K.; Kondo, H.; Hashizume, H.; Okazaki, Y.; Toyokuni, S.; Nakamura, K.; Yoshikawa, N.; et al. Oxidative stress-dependent and -independent death of glioblastoma cells induced by non-thermal plasma-exposed solutions. Sci. Rep. 2019, 9. [CrossRef]

68. Sato, Y.; Yamada, S.; Takeda, S.; Hattori, N.; Nakamura, K.; Tanaka, H.; Mizuno, M.; Hori, M.; Kodera, Y. Effect of Plasma-Activated Lactated Ringer's Solution on Pancreatic Cancer Cells In Vitro and In Vivo. Ann. Surg. Oncol. 2018, 25, 299-307. [CrossRef] [PubMed]

69. Bisag, A.; Bucci, C.; Coluccelli, S.; Girolimetti, G.; Laurita, R.; De Iaco, P.; Perrone, A.M.; Gherardi, M.; Marchio, L.; Porcelli, A.M.; et al. Plasma-activated Ringer's Lactate Solution Displays a Selective Cytotoxic Effect on Ovarian Cancer Cells. Cancers 2020, 12, 476. [CrossRef] [PubMed]

70. Mateu-Sanz, M.; Tornin, J.; Brulin, B.; Khlyustova, A.; Ginebra, M.P.; Layrolle, P.; Canal, C. Cold PlasmaTreated Ringer's Saline: A Weapon to Target Osteosarcoma. Cancers 2020, 12, 227. [CrossRef] [PubMed]

71. Haertel, B.; Hahnel, M.; Blackert, S.; Wende, K.; von Woedtke, T.; Lindequist, U. Surface molecules on HaCaT keratinocytes after interaction with non-thermal atmospheric pressure plasma. Cell Biol. Int. 2012, 36, 1217-1222. [CrossRef]

72. Haertel, B.; Straßenburg, S.; Oehmigen, K.; Wende, K.; von Woedtke, T.; Lindequist, U. Differential influence of components resulting from atmospheric-pressure plasma on integrin expression of human HaCaT keratinocytes. Biomed. Res. Int. 2013, 2013, 761451. [CrossRef] 
73. Shashurin, A.; Stepp, M.A.; Hawley, T.S.; Pal-Ghosh, S.; Brieda, L.; Bronnikov, S.; Jurjus, R.A.; Keidar, M. Influence of Cold Plasma Atmospheric Jet on Surface Integrin Expression of Living Cells. Plasma Process Polym. 2010, 7, 294-300. [CrossRef]

74. Volotskova, O.; Stepp, M.A.; Keidar, M. Integrin activation by a cold atmospheric plasma jet. New J. Phys. 2012, 14. [CrossRef]

75. Soltes, L.; Stankovska, M.; Kogan, G.; Gemeiner, P.; Stern, R. Contribution of oxidative-reductive reactions to high-molecular-weight hyaluronan catabolism. Chem. Biodivers. 2005, 2, 1242-1245. [CrossRef]

76. Saari, H.; Konttinen, Y.T.; Friman, C.; Sorsa, T. Differential-Effects of Reactive Oxygen Species on Native Synovial-Fluid and Purified Human Umbilical-Cord Hyaluronate. Inflammation 1993, 17, 403-415. [CrossRef]

77. Myint, P.; Deeble, D.J.; Beaumont, P.C.; Blake, S.M.; Phillips, G.O. The Reactivity of Various Free-Radicals with Hyaluronic-Acid-Steady-State and Pulse-Radiolysis Studies. Biochim. Et Biophys. Acta 1987, 925, 194-202. [CrossRef]

78. Weltmann, K.D.; Kindel, E.; Brandenburg, R.; Meyer, C.; Bussiahn, R.; Wilke, C.; von Woedtke, T. Atmospheric Pressure Plasma Jet for Medical Therapy: Plasma Parameters and Risk Estimation. Contrib. Plasm. Phys. 2009, 49, 631-640. [CrossRef]

79. Boukamp, P.; Petrussevska, R.T.; Breitkreutz, D.; Hornung, J.; Markham, A.; Fusenig, N.E. Normal keratinization in a spontaneously immortalized aneuploid human keratinocyte cell line. J. Cell Biol. 1988, 106, 761-771. [CrossRef] [PubMed]

80. Bergemann, C.; Rebl, H.; Otto, A.; Matschke, S.; Nebe, B. Pyruvate as a cell-protective agent during cold atmospheric plasma treatment in vitro: Impact on basic research for selective killing of tumor cells. Plasma Process Polym. 2019, 16. [CrossRef]

81. Pinhal, M.A.; Almeida, M.C.; Costa, A.S.; Theodoro, T.R.; Serrano, R.L.; Machado, C.D.F. Expression of heparanase in basal cell carcinoma and squamous cell carcinoma. An. Bras. Dermatol. 2016, 91, 595-600. [CrossRef]

82. Karvinen, S.; Kosma, V.-M.; Tammi, M.I.; Tammi, R. Hyaluronan, CD44 and versican in epidermal keratinocyte tumours. Br. J. Derm. 2003, 148, 86-94. [CrossRef]

83. Kosunen, A.; Ropponen, K.; Kellokoski, J.; Pukkila, M.; Virtaniemi, J.; Valtonen, H.; Kumpulainen, E.; Johansson, R.; Tammi, R.; Tammi, M.; et al. Reduced expression of hyaluronan is a strong indicator of poor survival in oral squamous cell carcinoma. Oral. Oncol. 2004, 40, 257-263. [CrossRef]

84. Kalghatgi, S.; Fridman, A.; Azizkhan-Clifford, J.; Friedman, G. DNA Damage in Mammalian Cells by Non-thermal Atmospheric Pressure Microsecond Pulsed Dielectric Barrier Discharge Plasma is not Mediated by Ozone. Plasma Process Polym. 2012, 9, 726-732. [CrossRef]

85. Yan, D.Y.; Sherman, J.H.; Keidar, M. Cold atmospheric plasma, a novel promising anti-cancer treatment modality. Oncotarget 2017, 8, 15977-15995. [CrossRef]

86. Girard, P.M.; Arbabian, A.; Fleury, M.; Bauville, G.; Puech, V.; Dutreix, M.; Sousa, J.S. Synergistic Effect of $\mathrm{H} 2 \mathrm{O} 2$ and NO2 in Cell Death Induced by Cold Atmospheric He Plasma. Sci. Rep. 2016, 6, 29098. [CrossRef] [PubMed]

87. Kurake, N.; Tanaka, H.; Ishikawa, K.; Kondo, T.; Sekine, M.; Nakamura, K.; Kajiyama, H.; Kikkawa, F.; Mizuno, M.; Hori, M. Cell survival of glioblastoma grown in medium containing hydrogen peroxide and/or nitrite, or in plasma-activated medium. Arch. Biochem. Biophys. 2016, 605, 102-108. [CrossRef] [PubMed]

88. Bogaerts, A.; Khosravian, N.; Van der Paal, J.; Verlackt, C.C.W.; Yusupov, M.; Kamaraj, B.; Neyts, E.C. Multi-level molecular modelling for plasma medicine. J. Phys. D Appl. Phys. 2016, 49. [CrossRef]

89. Xu, D.; Luo, X.; Xu, Y.; Cui, Q.; Yang, Y.; Liu, D.; Chen, H.; Kong, M.G. The effects of cold atmospheric plasma on cell adhesion, differentiation, migration, apoptosis and drug sensitivity of multiple myeloma. Biochem. Biophys. Res. Commun. 2016, 473, 1125-1132. [CrossRef]

(C) 2020 by the authors. Licensee MDPI, Basel, Switzerland. This article is an open access article distributed under the terms and conditions of the Creative Commons Attribution (CC BY) license (http://creativecommons.org/licenses/by/4.0/). 